Problems in Philosophy

BELIEF AND KNOWLEDGE

(7) 
Robert John Ackermann is professor of philosophy at the University of Massachusetts, Amherst, Massachusetts. He has been Fulbright Lecturer and Guggenheim Fellow in Philosophy. He has previously written Theories of Knowledge (McGraw-Hill, 1965), Nondeductive Inference (Routledge and Dover, 1966), An Introduction to Many-Valued Logics (Routledge and Dover, 1967), Modern Deductive Logic (Doubleday \& Company, Inc. and Macmillan, 1970), Philosophy of Science (Pegasus, 1970), and he has contributed widely to professional journals. 


\section{Problems in Philosophy}

\section{BELIEF \\ AND KNOWLEDGE \\ by \\ ROBERT J. ACKERMANN}

Macmillan Education 
ISBN 978-0-333-10938-0 ISBN 978-1-349-00881-0 (eBook)

DOI 10.1007/978-1-349-00881-0

(C) 1972 by Robert John Ackermann

Reprint of the original edition 1972

First published in the United States of America 1972

First published in the United Kingdom 1973 by

THE MACMILLAN PRESS LTD

London and Basingstoke

SBN 333109384 
ACKNOWLEDGMENT

I would like to take this opportunity to thank Bruce Aune, Steven Braude, Fred Feldman, Edmund L. Gettier, and Michael Hooker for their willingness to discuss certain problems that arose in connection with setting my mind straight about knowledge and belief in the course of writing this monograph. There are some matters on which I still disagree with each of them, but without their help, I could not have written a manuscript with which I would have been satisfied, given the space limitations of this series.

I should like to dedicate this volume to the series general editor, D. J. O'Connor-left-handed spin bowler, Chelsea fan, philosopher, and friend. 


\section{CONTENTS}

1. Kinds of Belief

2. Consistent Belief

3. Rational Belief

4. Kinds of Knowledge

5. Knowledge and Belief

6. Pragmatic Analysis

APPENDIX: Opacity of Belief and Knowledge Constructions

FURTHER READING 
BELIEF AND KNOWLEDGE 